\title{
Comparative evaluation of several methods for Canine Visceral Leishmaniasis diagnosis
}

\author{
Avaliação comparativa entre vários métodos para o diagnóstico da Leishmaniose Visceral Canina \\ Diogo Tiago da Silva ${ }^{1}$; Wilma Aparecida Starke-Buzetti ${ }^{1 *}$; Maria Fernanda Alves-Martin²; Mirian dos Santos Paixáo²; \\ Michely da Silva Tenório²; Mara Lúcia Martins Lopes ${ }^{3}$ \\ ${ }^{1}$ Departamento de Biologia e Zootecnia, Faculdade de Engenharia, Universidade Estadual Paulista - UNESP, Ilha Solteira, SP, Brasil \\ ${ }^{2}$ Departamento de Doenças Tropicais, Faculdade de Medicina, Universidade Estadual Paulista - UNESP, Botucatu, SP, Brasil \\ ${ }^{3}$ Departamento de Matemática, Faculdade de Engenharia, Universidade Estadual Paulista - UNESP, Ilha Solteira, SP, Brasil
}

Received December 16, 2013

Accepted February 17, 2014

\begin{abstract}
The aim of the present study was to evaluate the serological methods using ELISA with recombinant-rK39 (ELISA-rK-39) and soluble extract-SE (ELISA-SE) antigens, the indirect fluorescence antibody test (IFAT) in comparison to an immunochromatography rapid diagnostic test (RDT-rK39) and with a direct parasitological exam (PA) for Canine Visceral Leishmaniasis (CVL) diagnosis. The results showed that $89 \%(60 / 67)$ of the dogs were positive for at least one serological diagnostic test. ELISA-SE was the test that detected anti-Leishmania antibodies in the serum of the highest number of dogs (71.6\%) followed by ELISA-rK39 (65.7\%), IFAT (65.7\%) and RDT-rK39 (55.2\%). PA detected the lowest numbers (40.3\%) of positive dogs. In relation to the total of examined dogs, the Kappa indexes $(\mathrm{p} \leq 0.05)$ showed a good agreement between ELISA-SE and IFAT $(88.1 \% ; \mathrm{k}=0.7237)$, and it was also observed in the comparison of RDT-rK39 with ELISA-SE (83.6\%, $\mathrm{k}=0.6561)$, IFAT $(83.5 \%, \mathrm{k}=0.6605)$ and PA $(85.0 \%, \mathrm{k}=0.7074)$. A bad agreement was detected in any association of ELISA-rk39 with the other tests in either symptomatic or asymptomatic animals. ELISA as well as RDT using recombinant antigenic protein (rK39) were the methods that detected the lowest prevalence rates (33.3\%) of CVL in asymptomatic dogs. In conclusion, only one test does not adequately identify dogs with CVL and it is necessary the association of two or more diagnostic tests. Because of the good agreement indexes of RDT-rK39 when evaluated with ELISA-SE, IFAT and PA it was suggested as a complementary method to be used in association with either ELISA-SE or IFAT, particularly in the symptomatic dogs. Furthermore, new studies are recommended in order to improve the sensitivity of tests mainly for asymptomatic dogs.

Keywords: CVL, diagnosis, dogs, Leishmania infantum, rK39, RDT.
\end{abstract}

\section{Resumo}

O objetivo do presente estudo foi avaliar os métodos sorológicos usando ELISA (Ensaio Imunoenzimático Indireto) com o antígeno recombinante rK39 (ELISA-rK39) e o antígeno extrato solúvel bruto (ELISA-ES) e a RIFI (Reação de Imunofluorescência Indireta) em comparação com o método imunocromatográfico rápido (RDT-rK39) e o parasitológico direto (PA), para o diagnóstico da Leishmaniose Visceral Canina (LVC) em cães de Ilha Solteira, São Paulo, Brasil. Os resultados mostraram que 89\% (60/67) dos cães foram positivos por pelo menos um teste diagnóstico sorológico (RIFI, ELISA-ES, ELISA-rk39 ou RDT-rK39) e somente 40,3\% (27/67) foram positivos pelo PA. O ELISA-ES foi o teste que detectou anticorpos anti-Leishmania em maior número de cães $(71,6 \%)$ seguido por ELISArK39, RIFI (65,7\%) e por RDT-rK39 (55,2\%). No total de cáes analisados (assintomáticos e sintomáticos), o índice Kappa de concordância $(\mathrm{p} \leq 0,05)$ foi considerado de boa concordância entre ELISA-ES e IFAT $(88,1 \%$; $\mathrm{k}=0,7237)$ e entre RDT-rK39 com ELISA-ES (83,6\%, k= 0,6561), RIFI (83,5\%, k=0,6605) e PA (85,0\%, k= 0,7074). O índice de concordância ruim foi observado em qualquer associação de ELISA-rk39 com todos os outros testes nos animais sintomáticos e nos assintomáticos. Tanto o ELISA como o RDT com proteínas recombinantes (rK39) detectaram a

\footnotetext{
${ }^{*}$ Corresponding author: Wilma Aparecida Starke Buzetti

Departamento de Biologia e Zootecnia, Faculdade de Engenharia,

Universidade Estadual Paulista - UNESP, Av. Brasil, 56, CEP 15385-000, Ilha

Solteira, SP, Brazil

e-mail: starke@bio.feis.unesp.br
} 
menor porcentagem de cães assintomáticos $(33,3 \%)$ em relação aos outros testes sorológicos. Em conclusão, somente um método diagnóstico não foi suficiente para identificar todos os cães positivos com LVC, principalmente os assintomáticos e por isso foi necessário a associação de dois ou mais métodos. Em função da boa concordância do teste RDT-rK39 com ELISA-ES, RIFI e PA, o mesmo foi sugerido como um teste complementar ao ELISA-ES ou RIFI para o diagnóstico da LVC, principalmente dos cães sintomáticos. No entanto, novos estudos são recomendados para melhorar a sensibilidade dos testes principalmente para cães assintomáticos.

Palavras-chave: LVC, diagnóstico cães, Leishmania infantum, rK39, RDT.

\section{Introduction}

Canine Visceral Leishmaniasis (CVL) is a disease caused by Kinetoplastida protozoa that belongs to the genus Leishmania (ROSS, 1903). Leishmania infantum (syn. L. chagasi) is the causative agent of visceral leishmaniasis in the New World, with endemic regions extending from southern USA to northern Argentina, including Brazil (KUHLS et al., 2011).

The main route for parasite transmission to human and animals is through the sandfly's bite, Lutzomyia (L.) longipalpis (Diptera: Psychodidae: Phlebotominae) (PORROZZI et al., 2006). Thus, the canine skin is the body system that most commonly presents signs of the CVL, and the presence of Leishmania parasites in dog skin reinforces the important role played by domesticated canid in the L. infantum's life cycle (QUEIROZ et al., 2010).

Appropriate diagnostic tests are important in epidemiological studies and control programs, and for that reason the association of techniques may increase the positivity and contribute to the control of this canine disease (ASSIS et al., 2010; QUEIROZ et al., 2010). The detection of infected dogs can be made by serological analysis using an indirect fluorescence antibody test (IFAT or ELISA) or by the demonstration of the protozoan in parasitological methods (e. g., direct microscopic examination of amastigotes in smear). However, the sensitivity and the specificity of serological tests depend on the antigen, the protocol used in the laboratory, the time of infection and the serum conversion (COSTA et al., 1991; REITHINGER et al., 2002; FERREIRA et al., 2007); furthermore, the direct parasitological test is a very specific method, but the sensitivity is low and depends on the biological material and the parasitic burden (GENARO, 1993).

Specificity and sensitivity of the ELISA based immunoassay can be improved by using recombinant technology (BURNSJUNIOR et al., 1993; MOHAPATRA et al., 2010), which drives the expression and purification of diagnostically relevant proteins in large amounts (SUNDAR; RAI et al., 2002).

In the last two decades, several Leishmania antigens have been genetically and antigenically characterized. Recombinant K39 antigen (rK39) is a 39-amino-acid repetitive immunodominant B-cell epitope of the $230 \mathrm{kDa}$ kinesin related protein of L. chagasi (BURNS-JUNIOR et al., 1993; BADARÓ et al., 1996). The rK39 ELISA has proven to be suitable for detecting human and canine visceral leishmaniasis (VL) with the host producing specific antibodies against replicating Leishmania (QU et al., 1994; BADARÓ et al., 1996). Although, sera from patients and dogs with acute VL strongly recognized $\mathrm{rK} 39$, patients with asymptomatic or self-healing infections had low or undetectable levels of anti-rK39 antibodies (BADARÓ et al., 1996).
In another study, the performances of ELISA assays with different antigen preparations, such as Leishmania amazonensis or Leishmania chagasi lysates and the recombinant antigens $\mathrm{rK}-39$ and rK-26, were compared to detect anti-Leishmania antibodies in dogs from a visceral leishmaniasis-endemic area in Brazil. In this study, the sensitivities and specificities of crude and recombinant antigens were similar and remarkably high (96-100\%) identifying different clinical phases of canine leishmaniasis (ROSÁRIO et al., 2005).

Later, Mohapatra et al. (2010) designed a comparative evaluation of two recombinant hydrophilic antigens, rK9 and rK26 of L. chagasi along with rK39 and a crude soluble antigen (derived from Leishmania donovani promastigote) for the serodiagnosis of Indian visceral leishmaniasis patients by quantitative ELISA. The rK39 antigen was observed to be the most suitable antigen with $100 \%$ and $96 \%$ of sensitivity and specificity, respectively, in comparison to $\mathrm{rK} 26, \mathrm{rK} 9$ and and crude antigens.

The Leishmania rK39 Antibody Diagnostic Rapid Test (RDT) is a qualitative immunochromatography assay for detecting antibodies against $L$. donovani complex, that includes the $L$. donovani and $L$. infantum species, in whole blood, serum or plasma, but the diagnostic performance has been reported to be variable (QUINNELL et al., 2013). According to Quinnell et al. (2013) the sensitivity of this RDT method in infected dogs was relatively low (ranging from $46 \%$ to $78 \%$ ), suggesting that rK39 RDTs may be useful in a veterinary clinical setting, but is too low for operational control programs.

More recently, an immunochromatography assay (Dual-Path Platform - DPP ${ }^{\oplus}$ CVL kit) was developed to detect antibodies against the rK26/rK39 fusion protein. Grimaldi Jr et al. (2012) investigated the evaluation of this method for CVL diagnosis and indicated that this kit displays high specificity (96\%) but low sensitivity (47\%) to identify parasite-positive dogs without signs of CVL. However, the test's sensitivity was significantly higher $(98 \%)$ in disease cases, indicating that this convenient test may be useful to identify the most infectious dogs. Thus, this kit is unlikely to be sensitive enough for detecting asymptomatic canine carriers of $L$. infantum, but it may be useful for confirming clinically suspected cases due to its high specificity in symptomatic dogs (GRIMALDI JR et al., 2012).

As the euthanasia of positive dogs after serological exams is one of the most important CVL control measure, the use of appropriated diagnostic methods is decisive for the success of the control programs (REITHINGER et al., 2002); however, the efficacy of diagnostic methods is a challenge and more studies about this topic still necessary. Thus, the aim of the present study was to evaluate the serological methods using ELISA with recombinant-rK39 (ELISA-rK-39) and soluble extract-SE (ELISA-SE) antigens and an indirect fluorescence antibody test 
(IFAT) in comparison with the immunochromatography assay, a rapid diagnostic test (RDT-rK39) and a direct parasitological exam (PA) for CVL diagnosis in asymptomatic and symptomatic dogs from Ilha Solteira, São Paulo, Brazil.

\section{Materials and Methods}

\section{Animals and local of study}

The dogs of the present study belong to the Animal Protector Association shelter from Ilha Solteira, located in the northwestern region of the state of São Paulo, Brazil. According to Noronha Junior et al. (2007), Ilha Solteira is considered endemic for CVL, where the reported prevalence rates were $14 \%$ in the urban areas (PAULAN et al., 2012) and $37.7 \%$ in the rural areas (PAULAN et al., 2013).

The study was approved by the Animal Ethics Committee of São Paulo State University at Jaboticabal, under the Protocol no. $015863 / 09$. Sixty seven dogs from different breeds and ages, were clinically examined and divided into two groups according to their clinical leishmaniasis signs: asymptomatic - when they did not present any clinical sign $(n=12)$; or symptomatic - when they presented at least one clinical sign $(n=55)$. The main clinical signs were onychogryphosis, lymphadenomegaly, weight lost, skin lesions, apathy, opaque bristles and/or alopecia, conjunctivitis and anemia.

\section{Parasitological exams}

For parasitological exams (PA), smears of popliteal lymph node aspirates were fixed in methanol, stained with Giemsa (4\%) for 20 minutes and were directly examined under a light microscope (1000x magnification) for the detection of Leishmania amastigotes. At least 200 microscopic fields were examined for each slide.

\section{Indirect Fluorescence Antibody Test (IFAT)}

The detection of antibodies against $L$. infantum by IFAT was performed according to the procedure of Oliveira et al. (2008) as briefly described: Leishmania parasites were isolated from the bone marrow of naturally infected dogs and maintained on a RPMI-1640 medium at $25^{\circ} \mathrm{C}$. For IFAT procedure, Leishmania promastigotes maintained in culture medium were used for antigen preparation. In duplicate, the serum dilutions were used, starting at $1: 40$ and placed over the antigen on the slides at $37^{\circ} \mathrm{C}$ for 30 minutes, and then subjected to three washes in PBS $(0.01 \mathrm{M}$, $\mathrm{pH} 7.4$ ) by immersion, five minutes each. After drying at room temperature, the slides were incubated with anti-dog IgG serum conjugated for fluorescein isothiocyanate (KPL, cat no 02-19-02, USA), diluted at $1: 30$ in PBS containing $1 \mathrm{mg} \%$ of Evan's Blue. The slides were washed again in PBS, covered with buffered glycerin and a cover slip, and then examined under a fluorescent microscope (Olympus, BX-FLA, Japan). In all the experiments, reference sera were included as negative and positive controls. For positive serum samples, parasites displayed a bright-green peripheral stain with a dull fluorescence of the cytoplasm and were considered positive serum samples at 1:40 or more (cut-off point).

\section{Enzime-Linked Immunosorbent Assay (ELISA)}

\section{Soluble extract antigens of L. infantum (SE)}

An indirect ELISA method (OLIVEIRA et al., 2008) was used for Leishmania antibodies. $100 \mu \mathrm{l}$ of crude soluble extract of $L$. infantum antigen (ELISA-SE) was diluted in a sodium carbonatebicarbonate buffer (0.05M, pH 9.6) and was added to each ELISA microplate, sealed and overnight incubated at $4{ }^{\circ} \mathrm{C}$ in a humid chamber. Antigen protein concentration was determined at $5 \mu \mathrm{g} /$ $\mathrm{ml}$. After coating the plates with antigens, the plates were blocked for one hour at $37{ }^{\circ} \mathrm{C}$ with $6 \%$ powered milk diluted in $0.05 \mathrm{M}$ carbonate/bicarbonate buffer at $\mathrm{pH}$ 9.6. After wash (3 min each), $100 \mu \mathrm{l}$ of diluted dog serum (1/400) in PBS-Tween-20 plus 5\% normal rabbit serum was added in duplicates to the plate and incubated in a humid chamber at $37^{\circ} \mathrm{C}$ for $60 \mathrm{~min}$. Following, a $100 \mu$ l of alkaline phosphatase conjugate rabbit anti-dog IgG whole molecule (Sigma, cat. no A 0793, USA) at 1:8000 dilution plus $0,5 \%$ normal rabbit serum was added to each well and incubated at $37^{\circ} \mathrm{C}$ for $60 \mathrm{~min}$ in a humid chamber. After the washings, $100 \mu \mathrm{l}$ of P-nitrophenyl phosphate (Sigma, cat. no N-9389, USA) at $1 \mathrm{mg} / \mathrm{ml}$ in diethanolamine buffer, $\mathrm{pH}$ 9.8, was added and incubated for $45 \mathrm{~min}$ at room temperature. The reaction was stopped by adding $50 \mu \mathrm{l}$ of $3 \mathrm{M}$ sodium hydroxide and the plates were read at $406 \mathrm{~nm}$ wavelengths using a microplate reader (Dynex Technologies, USA). To control inter-plate variation, positive and negative controls were included in each plate.

The ELISA system calibration was done according to Oliveira et al. (2008), using positive reference sera collected from Leishmania symptomatic dogs and negative reference sera from Leishmania negative dogs. The negative reference sera were samples collected from dogs living in a non-endemic areas. The enzymatic activity of each serum sample was determined by calculating the sample $(\mathrm{S})$ for the positive $(\mathrm{P})$, rate $(\mathrm{S} / \mathrm{P})$ at each dilution, considering positive and negative serum references. The cut off point was determined to be ELISA level (EL $\geq 3$ ).

\section{Recombinant K39 (rK39) antigen}

For ELISA using rK39 of L. infantum (ELISA-rK39), the antigenic protein concentration was determined at $200 \mathrm{ng} / \mathrm{mL}$. After coating the plates with antigens, the plates were blocked for one hour at $37^{\circ} \mathrm{C}$ with $5 \%$ powered milk diluted in $0.05 \mathrm{M}$ carbonate/bicarbonate buffer at $\mathrm{pH}$ 9.6. Dog sera were diluted at 1/50 in PBS-Tween-20. Following the incubation with dog sera, $100 \mu \mathrm{l}$ aliquot of alkaline phosphatase conjugate rabbit anti-dog IgG whole molecule (Sigma, cat no A 0793, USA) was diluted at $1: 4000$, plus $0.5 \%$ normal rabbit serum added to each well, followed by incubation at $37^{\circ} \mathrm{C}$ for $60 \mathrm{~min}$ in a humid chamber. The reaction was detected by the substrate P-nitrophenyl phosphate (Sigma, N-9389, USA). 
The calibration of the ELISA system and the enzymatic activity of each serum sample were determined as described above in 4.1. item. The cutoff point was determined to be $\mathrm{EL} \geq 3$.

\section{Sensit Leishmania rK39 Antibody Rapid Diagnostic Test (RDT-rK39)}

The Sensit Leishmania rK39 Antibody Diagnostic Rapid Test (RDT-rK39) is a qualitative immunochromatography assay for detecting antibodies to Leismania donovani complex that includes the $L$. donovani and $L$. infantum species in whole blood, serum or plasma. The RDT-rK39 kit obtained from Ubio Biotechnology Systems Pvt Ltd, Cochin Kerala, India, was used according to the manufacturer's instructions. The appearance of a red line in the test area, even a faint one, was interpreted as positive, following manufacturer's recommendations; all tested samples were classified as either positive or negative. All reactions were performed by the same person, who was not blind to the results of the reference tests.

\section{Statistical analysis}

The results of diagnostic methods were submitted for statistical analysis using Fortran Power station (version 4) program (University of Economics and Business. Austria), In order to evaluate the concurrence index among diagnostic methods, the Kappa index of agreement (at the 95\% confidence interval) was used. According to Landis and Koch (1977), $\mathrm{k}<0.4$ is consider bad; $0.41 \geq \kappa \leq 0.60$ is accept as moderate agreement; $0.61 \geq \kappa \leq 0.80$ is a good agreement, and $\kappa>0.8$ is an excellent agreement.

The chi-square test with a significance level of $5 \%$ was calculated using the R system (R Development Core Team, 2013) in order to assess the associations between the positivity of asymptomatic and symptomatic dogs in each diagnostic method (RDT, ELISASE, ELISA-rK39, IFAT and PA) for CVL.

\section{Results and Discussion}

In order to conduct this study, 67 dogs of different breeds and ages, from the animal shelter were examined according to their clinical status and by several laboratorial tests for CVL diagnosis. Thus, according to their clinical signs, 55/67 (82.1\%) dogs were classified as symptomatic and the most frequent clinical signs were onycogryphosis $(35 / 55,63.6 \%)$, alopecia $(33 / 55,60 \%)$, emaciation $(30 / 55,54.5 \%)$, hypertrophic lymph nodes $(18 / 55$,
$32.7 \%)$ and corneal opacity $(15 / 55,27.3 \%)$. In contrast, 12/67 (17.9\%) dogs were classified as asymptomatic.

One of the greatest challenges for the disease control strategy in dogs is regarding about the appropriate diagnosis. It is clear that the precise CVL diagnosis is complex and due the fact that the infected dogs have multiple clinical aspects and no specific clinical pathological alterations, reinforce the need for a combination of two or more laboratorial methods for canine diagnosis (ASSIS et al., 2010; QUEIROZ et al., 2010; PALTRINIERI et al., 2010). Furthermore, the diagnostic performance has been reported to be variable, with some disagreements about the results of specificity and sensibility of methods in different studies (BADARÓ et al., 1983; REITHINGER et al., 2002; GOMES et al., 2008). Thus, the sensitivity and specificity of diagnostic methods are dependent of the type of antigen (e.g., crude or recombinant, parasite species, promastigotes or amastigotes, etc), the time of infection and changes to the standard experimental protocol (BADARÓ et al., 1983). We evaluate the serological methods using ELISA with two different types of antigens (crude soluble extract and rK39) and IFAT in comparison with RDT-rK39 and PA, and the results showed that $89 \%(60 / 67)$ of the dogs were positive for at least one serological diagnostic test, but none of the methods tested in this study was able to detect all positive dogs when individually evaluated, and for that reason it was necessary a combination of two or more methods.

The PA is a very specific method for CVL diagnosis, since it detects the parasites in the tissues, including biopsies or/and aspirates of bone marrow, lymph nodes, spleen, liver or skin (ALVAR et al., 2004; MOREIRA et al., 2007; TASCA et al., 2009; ASSIS et al., 2010; QUEIROZ et al., 2010). However, the sensitivity of this method is low, depending on biologic material, parasitic load and animal's clinical status (GENARO, 1993). In the present study, only $23 / 55$ (41.8\%) of symptomatic dogs had Leishmania amastigotes in samples of popliteal lymph node aspirates, and it was the lowest prevalence rate of positivism in comparison with ELISA, IFAT or RDT, which the difference was statistical significant ( $\mathrm{p} \leq 0.05)$ (Table 1$)$. For that reason, serological exams are currently used for mass-screening surveys instead of parasitological exams.

However, it is important to mention that all positive dogs by ELISA-SE (Figure 1a), IFAT (Figure 1c) or RDT-rK39 (Figure 1d), were also simultaneously positive by PA (40.3\%) reinforcing the low sensitivity, but the high specificity of PA as a diagnostic method for CVL diagnosis (GENARO, 1993; BRASIL, 2003). Moreover, the Kappa indexes (Table 2) showed a moderate

Table 1. Numbers and percentages (No/\%) of positive dogs for Canine Visceral Leishmaniosis (CVL) by serological (ELISA-SE, ELISA-rk39, IFAT and RDT) and parasitological direct exams (PA) in asymptomatic (A) and symptomatic (S) dogs, Ilha Solteira, São Paulo, Brazil, 2013.

\begin{tabular}{|c|c|c|c|c|c|}
\hline \multicolumn{6}{|c|}{ Numbers / percentages of positive dogs by CVL } \\
\hline Groups $(\mathrm{N})$ & Elisa-SE & Elisa-rk39 & IFAT & RDT & PA \\
\hline$A(\mathrm{~N}=12)$ & $7 / 58.3^{\mathrm{aA}}$ & $4 / 33.3^{\mathrm{aA}}$ & $6 / 50.0^{\mathrm{aA}}$ & $4 / 33.3^{\mathrm{aA}}$ & $4 / 33.3^{\mathrm{aA}}$ \\
\hline $\mathbf{S}(\mathrm{N}=55)$ & $41 / 74.5^{\mathrm{aA}}$ & $40 / 72.7^{\mathrm{aB}}$ & $38 / 69.1^{\mathrm{aA}}$ & $33 / 60.0^{\mathrm{aA}}$ & $23 / 41.8^{\mathrm{bA}}$ \\
\hline $\mathbf{T}(\mathrm{N}=67)$ & $48 / 71.6$ & $44 / 65.7$ & $44 / 65.7$ & $37 / 55.2$ & $27 / 40.3$ \\
\hline
\end{tabular}

(a/b) Proportions with the same small letters in lines are not significantly different $(\mathrm{P}<0.5)$. (A/B) Proportions with the same capital letters in columns are not significantly different $(\mathrm{P}<0.5)$. Chi-square test. 

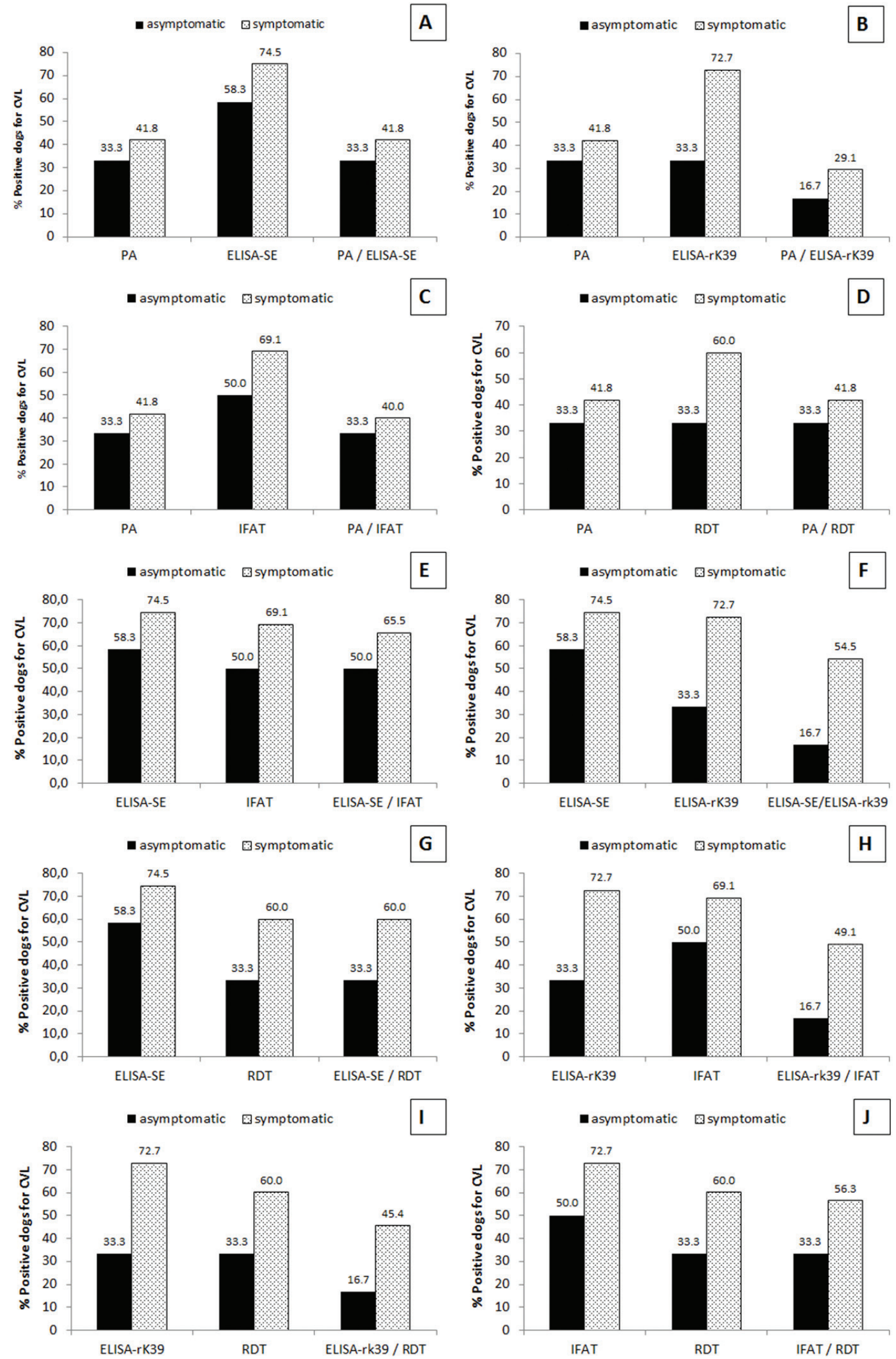

Figure 1. Results of positive dogs for Canine Visceral Leishmaniosis (CVL) compared two by two in symptomatic ( $\mathrm{n}=55)$ and asymptomatic dogs (n=12) Ilha Solteira São Paulo, Brazil, 2013. 
Table 2. Comparative analysis of diagnostic methods for Canine Visceral Leishmaniosis (CVL) in dogs classified in asymptomatic (A) and symptomatic (S). Ilha Solteira, São Paulo, Brazil, 2013.

\section{Concordances between diagnostic methods} Number of dogs / Percentage

\begin{tabular}{|c|c|c|c|c|c|}
\hline Techniques & & $\begin{array}{c}\mathbf{A} \\
(\mathrm{N}=12)\end{array}$ & $\begin{array}{c}S \\
(N=55)\end{array}$ & $\begin{array}{c}\text { Kappa Index } \\
(\kappa)\end{array}$ & $\begin{array}{c}\text { Total } \\
(\mathrm{N}=67)\end{array}$ \\
\hline \multirow[t]{2}{*}{ Elisa-rK39 x Elisa-SE } & & $05 / 41.6$ & $34 / 61.8$ & 0.0330 & $39 / 58.2$ \\
\hline & $\kappa$ & -0.1053 & 0.0170 & $\mathrm{Bad}$ & \\
\hline \multirow[t]{2}{*}{ Elisa-rK39 x IFAT } & & $06 / 50.0$ & $31 / 56.4$ & 0.0069 & $37 / 55.2$ \\
\hline & $\kappa$ & 0,0000 & -0.0560 & Bad & \\
\hline \multirow[t]{2}{*}{ Elisa-rK39 x PA } & & $08 / 66.7$ & $24 / 43.6$ & 0.0151 & $32 / 47.8$ \\
\hline & $\kappa$ & 0.2500 & -0.0492 & Bad & \\
\hline \multirow[t]{2}{*}{ Elisa-rK39 x RDT-rK39 } & & $08 / 66.7$ & $32 / 58.1$ & 0.1667 & $40 / 59.7$ \\
\hline & $\kappa$ & 0.2500 & 0.0800 & Bad & \\
\hline \multirow{2}{*}{ Elisa-SE x IFAT } & & $11 / 91.7$ & $48 / 87.3$ & 0.7237 & $59 / 88.1$ \\
\hline & $\kappa$ & 0.8333 & 0.6867 & Good & \\
\hline \multirow[t]{2}{*}{ Elisa-SE x PA } & & $09 / 75.0$ & $37 / 67.3$ & 0.4217 & $46 / 68.7$ \\
\hline & $\kappa$ & 0.5263 & 0.3941 & Moderate & \\
\hline \multirow[t]{2}{*}{ Elisa-SE x RDT-rK39 } & & $09 / 75.0$ & $47 / 85.4$ & 0.6561 & $56 / 83.6$ \\
\hline & $\kappa$ & 0.5263 & 0.6774 & Good & \\
\hline \multirow[t]{2}{*}{ IFAT x PA } & & $10 / 83.3$ & $38 / 691$ & 0.4654 & $48 / 71.6$ \\
\hline & $\kappa$ & 0.6667 & 04182 & Moderate & \\
\hline \multirow[t]{2}{*}{ IFAT x RDT-rK39 } & & $10 / 83.3$ & $46 / 83.6$ & 0.6605 & $56 / 83.5$ \\
\hline & $\kappa$ & 0.6667 & 0.6457 & Good & \\
\hline \multirow[t]{2}{*}{ RDT-rK39 x PA } & & $12 / 100.0$ & $45 / 81.8$ & 0.7074 & $57 / 85.0$ \\
\hline & $\kappa$ & 1.000 & 0.6479 & Good & \\
\hline
\end{tabular}

Elisa-rK39 (ELISA recombinant K39 antigen); Elisa-SE (ELISA crude extract soluble antigen); IFAT (indirect fluorescent antibody test); RDT-rK39 (Rapid Diagnostic Test-rK39 antigen); PA (Parasitological direct test); ( $)$ = Kappa Index; A= asymptomatic; $S=$ symptomatic.

agreement between PA x ELISA-SE $(68.7 \%, \mathrm{k}=0.4217)$ and between PA $\times$ IFAT $(71.6 \%, \mathrm{k}=0.4654)$, but a good agreement between PA $\times$ RDT-rK39 was observed for symptomatic animals $(81.8 \%, \mathrm{k}=0.6579)$.

According to the tests, the positivism rates for CVL were the following: $71.6 \%$ (48/67), 65.7\% (44/67), 65.7\% (44/67) and $55.2 \%(37 / 67)$ by ELISA-SE, ELISA-rk39, IFAT and RDT-rK39, respectively. Furthermore, the results showed that the serum prevalence rates were higher in symptomatic rather than in asymptomatic dogs (Table 1) in accordance to the results of Assis et al. (2010) and Queiroz et al. (2010), who compared different diagnostic tests in a group of CVL positive dogs.

When ELISA-SE and IFAT were individually or simultaneously analyzed (Figure 1e), the data showed similar numbers of positive dogs in both exams, not only symptomatic but also asymptomatic dogs. The Kappa indexes of agreement (Table 2) between both serological methods (ELISA-SE $\times$ IFAT) were considered good in the symptomatic $(87.3 \%, \mathrm{k}=0.6867)$ and excellent in the asymptomatic group $(91.7 \%, \mathrm{k}=0.8333)$. Similarly, Assis et al. (2010) observed also a good concordance between ELISA-SE and IFAT, indicating that either ELISA or IFAT can be recommended for CVL diagnosis during epidemiological surveys.

Moreover similar results were not observed by ELISA-rK39 when individually or simultaneously compared with PA (Figure 1b), ELISA-SE (Figure 1f), IFAT (Figure 1h) or RDT-rK39 (Figure 1i). Firstly, because ELISA-rK39 reacted with much lower numbers of asymptomatic (33.3\%) in comparison with symptomatic dogs
(72.7\%) with statistically significant difference (Table 1). Secondly, because the Kappa indexes of ELISA-rK39 indicated a bad agreement in the association with ELISA-SE $(58.2 \%, \mathrm{k}=0.0330)$, IFAT $(55.2 \%, \mathrm{k}=0.0069)$, RDT-rK39 (59.7\%, $\mathrm{k}=0.1667)$ and PA $(47.8 \%, k=0.0151)$ independently of the clinical signs of the dogs (Table 2). Similar results were found by Zijlstra et al. (2001) reporting low sensitivity of the $\mathrm{rK}-39$ antigen when a strip test was used in comparison with direct agglutination (DAT) that was $67 \%$ and $90 \%$, respectively, with an agreement of only $69 \%$ between both diagnostic tests.

More recently, immunochromatography assays have been developed (e. g., rapid diagnostic tests - RDTs) in order to detect antibodies against one or more types of recombinant proteins of the parasite. In this work, we also analyzed one RDT kit containing one recombinant antigen, (RDT-rK39). In comparison with serological and parasitological exams, all positive dogs diagnosed by this kit were confirmed by ELISA-SE (Figure 1g), ELISA-rK39 (Figure 1i) or IFAT (Figure 1j); even though, this kit detected lower numbers of positive dogs (55.2\%) than ELISA-SE (71.6\%), ELISA-rK39 $(65.7 \%)$ and IFAT (65.7\%). Furthermore, our studies showed that the Kappa indexes of agreement of RDT-rk39 were good when compared to ELISA-SE (83.6\%, $\mathrm{k}=0.6561)$, IFAT $(83.5 \%, \mathrm{k}=$ $0.6605)$ and PA (85.0\%, $\mathrm{k}=0.7074)$, particularly in symptomatic dogs (Table 2). These good agreement indexes suggest that RDT may be another option to be used as a complementary method in association with either ELISA or IFAT or PA for CVL diagnosis. 
Moreover, this study showed that RDT-rK39 and ELISA-rK39 detected lower numbers of positive asymptomatic dogs (33.3\%) than symptomatic (60\%-72.7\%) demonstrating the poor efficacy of recombinant protein for the detection of infection in asymptomatic dogs. Similarly, Quinnell et al. (2013) reported higher sensitivity (99.7\%) of recombinant K39 protein when used in the RDT only in dogs with clinical disease, but not in asymptomatic dogs. In other studies, the immunochromatographic tests using protein $\mathrm{k} 39$ as antigen, detected sensitivities ranging from $91.5 \%$ to $96.7 \%$ in symptomatic dogs (METTLER et al., 2005; LIMA et al., 2010) and only $52.9 \%$ in asymptomatic dogs (METTLER et al., 2005). According to the clinical progression of the disease, from asymptomatic to symptomatic, higher specific antibodies tend to increase with the infection's development (DEPLAZES et al., 1995), which may explain the low concentration of anti-Leishmania antibodies in asymptomatic dogs, while crude soluble extract (SE) may identify different clinical phases of canine leishmaniasis.

The heterogeneous humoral immune response that develops in dogs infected by L. infantum (DEPLAZES et al., 1995; SOLANOGALLEGO et al., 2001) likely involves multiple antigens that are differentially recognized in different animals and different stages of disease in the same host (FALQUETO et al., 2009). These results suggest that low sensitivity to detect asymptomatic infections may due to the use of a single defined antigen. Thus, the development of RDTs using multiple defined antigens (rK39) may increase the sensitivity in asymptomatic dogs.

In Brazil, the Public Health Services recommend two serological diagnostic tests for epidemiological surveys and CVL control: the RDT (detecting antibodies against rK26 and rK39 antigens) for screening and ELISA as a confirmatory test (BRASIL, 2013). Nonetheless, recent tests of a RDT incorporating both rK26 and rK39 showed low sensitivity (47\%) to detect asymptomatic canine infections (GRIMALDI JR et al., 2012). In accordance with Quinnell et al. (2013), RDT is a reasonable method for confirmation of infection in suspected clinical cases, but due the low sensitivity to detect asymptomatic infected dogs it is not indicated for large-scale epidemiological studies and operational control programs, which many dogs could be misdiagnosed as false negatives, leading to a failed control campaign. However, in this paper, RDT-rK39 presented good indexes of concordance with ELISA-SE, IFAT and PA, and when used as a screening test, could permit a faster removal of infected symptomatic reservoirs from the environment, stopping the transmission of parasites to susceptible uninfected dogs.

The results of this comparative evaluation among several diagnostic methods reinforce that only one test does not adequately identify the dogs with CVL and for that reason it is necessary a combination of different methods. All tests used in this study showed poor efficacy for detecting infection in asymptomatic dogs, particularly with recombinant protein K39. Therefore, RDT-recombinant antigenic proteins should be used only as a complementary method in association with either ELISA or IFAT, because of the good concordance among these methods, particularly in the symptomatic dogs. Furthermore, additional studies are recommended for the development of new technologies to increase the sensitivity of diagnostic methods mainly for asymptomatic dogs.

\section{Acknowledgements}

To Brazilian Research Funding Agency FAPESP and the Zoonotic Disease Control Center (CCZ) of Ilha Solteira. To the Infectious Disease Research Institute (IDRI), Seatle, Washington, EUA that kindly donated the recombinant K39 antigen of L. infantum.

\section{References}

Alvar J, Cañavate C, Molina R, Moreno J, Nieto J. Canine leishmaniasis. Adv Parasitol 2004; 57: 1-88. http://dx.doi.org/10.1016/S0065308X(04)57001-X

Assis J, Queiroz NMGP, Silveira RCV, Nunes CM, Oliveira TMFS, Noronha Junior ACF, et al. Estudo comparativo dos métodos diagnósticos para Leishmaniose Visceral em cães oriundos de Ilha Solteira, SP. Jaboticabal. Rev Bras Parasitol Vet 2010; 19(1): 17-25. PMid:20385055. http://dx.doi.org/10.4322/rbpv.01901004

Badaró R, Reed SG, Carvalho EM. Immunofluorescent antibody test in American Visceral leishmaniasis: sensitivity and specificity of different morphological forms of two Leishmania species. Am J Trop Med Hyg 1983; 32(3): 480-484. PMid:6407345.

Badaró R, Benson D, Eulálio MC, Freire M, Cunha S, Netto EM, et al. rK-39: a cloned antigen of Leishmania chagasi that predicts active visceral leishmaniasis. J Infect Dis 1996; 173(3): 758-761. PMid:8627048. http:// dx.doi.org/10.1093/infdis/173.3.758

Brasil. Ministério da Saúde. Manual de vigilância e controle da Leishmaniose Visceral: Normas e Manuais Técnicos. Brasília: Ministério da Saúde; 2003. 120 p.

Brasil. Diretoria de Vigilância Epidemiológica de Santa Catarina. Guia de Orientação para Vigilância de Leishmaniose Visceral Canina. 2013. Material elaborado por grupo técnico intersetorial. [cited 2014 Mar 31]. Available from: http://www.dive.sc.gov.br/conteudos/zoonoses/Vetores/ leishmanioses/Guia_Básico_de_Orientacao_Leishmaniose_Visceral_ Canina.pdf.

Burns-Junior JM, Shreffler WG, Benson DR, Ghalib HW, Badaró R, Reed SG. Molecular characterization of a kinesin-related antigen of Leishmania chagasi that detects specific antibody in African and American visceral leishmaniasis. Proc Natl Acad Sci USA 1993; 90(2):775-779. http://dx.doi.org/10.1073/pnas.90.2.775

Costa CA, Genaro O, Lana M, Magalhães PA, Dias M, Michalick MS, et al. Canine visceral leishmaniasis: evaluation of the serologic method used in epidemiologic studies Rev Soc Bra Med Trop 1991; 24(1): 21-25.

Deplazes P, Smith NC, Arnold P, Lutz H, Eckert J. Specific IgG1 and IgG2 antibody responses of dogs to Leishmania infantum and other parasites. Parasite Immunol 1995; 17(9): 451-458. PMid:8552413. http:// dx.doi.org/10.1111/j.1365-3024.1995.tb00914.x

Falqueto A, Ferreira AL, Dos Santos CB, Porrozzi R, Da Costa MV, Teva A, et al. Cross-sectional and longitudinal epidemiologic surveys of human and canine Leishmania infantum visceral infections in an endemic rural area of Southeast Brazil (Pancas, Espírito Santo). Am J Trop Med Hyg 2009; 80(4):559-565. PMid:19346375.

Ferreira EC, Lana M, Carneiro M, Reis AB, Paes DV, Silva ES, et al. Comparison of serological assays for the diagnosis of canine visceral leishmaniasis in animals presenting different clinical manifestations. Vet Parasitol 2007; 146(3-4): 235-241. PMid:17403582. http://dx.doi. org/10.1016/j.vetpar.2007.02.015

Genaro O. Leishmaniose visceral canina experimental [Tese]. Belo Horizonte: Universidade Federal de Minas Gerais; 1993. 
Gomes YM, Paiva Cavalcanti M, Lira RA, Abath FGC, Alves LC. Diagnosis of canine visceral leishmaniasis: Biotechnological advances. Vet J 2008; 175(1): 45-52. PMid:17150389. http://dx.doi.org/10.1016/j. tvj1.2006.10.019

Grimaldi Jr G, Teva A, Ferreira AL, Santos CB, Pinto IS, Azevedo CT, et al. Evaluation of a novel chromatographic immunoassay based on Dual-Path Platform technology (DPPR CVL rapid test) for the serodiagnosis of canine visceral leishmaniasis. Trans $R$ Soc Trop Med Hyg 2012; 106(1): 54-59. PMid:22137538. http://dx.doi.org/10.1016/j. trstmh.2011.10.001

Kuhls K, Alam MZ, Cupolillo E, Ferreira GEM, Mauricio IL, Oddone R, et al. Comparative microsatellite typing of new world Leishmania infantum reveals low heterogeneity among populations and its recent old world origin. PLoS Negl Trop Dis 2011; 5(6): e1155. PMid:21666787 PMCid:PMC3110170. http://dx.doi.org/10.1371/ journal.pntd.0001155

Landis JR, Koch GG. The measurement of observer agreement for categorical data. Biometrics 1977; 33(1): 159-174. http://dx.doi. org/10.2307/2529310

Lima VMF, Fattori KR, Michelin AF, Neto LS, Vasconcelos RO. Comparison between ELISA using total antigen and immunochromatography with antigen rK39 in the diagnosis of canine visceral leishmaniasis. Vet Parasitol 2010; 173(3-4): 330-333. PMid:20810216. http://dx.doi.org/10.1016/j.vetpar.2010.07.012

Mettler M, Grimm F, Capelli G, Camp H, Deplazes P. Evaluation of enzyme-linked immunosorbent assays, an immunofluorescent-antibody test, and two rapid tests (Immunochromatographic-Dipstick and Gel Tests) for serological diagnosis of symptomatic and asymptomatic Leishmania infections in dogs. J Clinic Microbiol 2005; 43(11): 55155519. PMid:16272479 PMCid:PMC1287801. http://dx.doi. org/10.1128/JCM.43.11.5515-5519.2005

Mohapatra TM, Singh DP, Sem MR, Bharti K, Sundar S. Comparative evaluation of rK9, rK26 and rK39 antigens in the serodiagnosis of Indian visceral leishmaniasis. J Infect Dev Ctries 2010; 4(2): 114-117. PMid:20212344. http://dx.doi.org/10.3855/jidc.544

Moreira MAB, Luvizotto MCR, Garcia JF, Corbett CEP, Laurenti MD. Comparison of parasitological, immunological and molecular methods for the diagnosis of Leishmaniasis in dogs with different clinical signs. Vet Parasitol 2007; 145(3-4): 245-252. PMid:17257764. http://dx.doi. org/10.1016/j.vetpar.2006.12.012

Noronha Junior ACF, Assis J, Dobre PR, Queiroz NMGP, Silveira RCV, Starke-Buzetti WA, et al. Leishmaniose Visceral Canina (LVC) em cães do município de Ilha Solteira, SP, Brasil. Ciên Agr Saúde FEA 2007; 7(1): 32-36.

Oliveira TMFS, Furuta PI, Carvalho D, Machado RZ. A study of cross-reactivity in serum samples from dogs positive for Leishmania sp., Babesia canis and Ehrlichia canis in enzyme-linked immunosorbent assay and indirect fluorescent antibody test. Rev Bras Parasitol Vet 2008; 17(1): 7-11. PMid:18554433.

Paltrinieri S, Solano-Gallego L, Fondati A, Lubas G, Gradoni L, Castagnaro $\mathrm{M}$, et al. Guidelines for diagnosis and clinical classification of leishmaniasis in dogs. J Am Vet Med Assoc 2010; 236(11): 1184-1191. PMid:20513195. http://dx.doi.org/10.2460/javma.236.11.1184

Paulan SC, Lins AGS, Tenório MS, Silva DT, Pena HFJ, Machado RZ, et al. Seroprevalence rates of antibodies against Leishmania infantum and other protozoan and rickettsial parasites in dogs. Rev Bras Parasitol Vet 2013; 22(1): 162-166. http://dx.doi.org/10.1590/S198429612013000100031

Paulan SC, Silva HR, Lima EACF, Flores EF, Tachibana VM, Kanda ZC, et al. Spatial distribution of Canine Visceral Leishmaniasis in Ilha
Solteira, São Paulo Brazil. Eng Agríc 2012; 32(4): 765-774. http://dx.doi. org/10.1590/S0100-69162012000400016

Porrozzi R, Pereira MS, Teva A, Volpini AC, Pinto MA, Marchevsky RS, et al. Leishmania infantum-induced primary and challenge infections in rhesus monkeys (Macaca mulatta): a primate model for visceral leishmaniasis. Trans R Soc Trop Med Hyg 2006; 100(10): 926-937. PMid:16455120. http://dx.doi.org/10.1016/j.trstmh.2005.11.005

Queiroz NMGP, Assis J, Oliveira TMFS, Machado RZ, Nunes CM, Starke-Buzetti WA. Diagnóstico da Leishmaniose Visceral Canina pelas técnicas de imunoistoquímica e PCR em tecidos cutâneos e associação com a RIFI e ELISA-teste. Rev Bras Parasitol Vet 2010; 19(1): 32-38. PMid:20385057. http://dx.doi.org/10.4322/rbpv.01901006

Quinnell RJ, Carson CC, Reithinger R, Garcez LM, Courtenay O. Evaluation of rK39 Rapid Diagnostic Tests for Canine Visceral Leishmaniasis: Longitudinal Study and Meta-Analysis. PLoS Negl Trop Dis 2013; 7 (1): e1992. http://dx.doi.org/10.1371/journal.pntd.0001992

Qu JQ, Zhong L, Masoom-Yasinzai M, Abdur-Rab M, Aksu HSZ, Reed SG, et al. Serodiagnosis of Asian leishmaniasis with a recombinant antigen from the repetitive domain of a Leishmania kinesin. Trans $R$ Soc Trop Med Hyg 1994; 88(5): 543-545. http://dx.doi.org/10.1016/00359203(94)90154-6

R CoreTeam RC. R: A language and enviroment for statistical computing [online]. Vienna: R Foundation for Statistical Computing; 2013 [cited 2013 Mar 31]. ISBN 3-900051-07-0. Available from: http://www.Rproject.org/

Reithinger R, Quinnell RJ, Alexander B, Davies CR. Rapid detection of Leishmania infantum infection in dogs: comparative study using an immunochromatographic dipstick test, enzyme-linked immunosorbent assay, and PCR. J Clin Microbiol 2002; 40(7): 2352 2356. PMid:12089247 PMCid:PMC120577. http://dx.doi.org/10.1128/ JCM.40.7.2352-2356.2002

Rosário EY, Genaro O, França-Silva JC, Costa RT, Mayrink W, Reis $\mathrm{AB}$, et al. Evaluation of enzyme-linked immunosorbent assay using crude Leishmania and recombinant antigens as a diagnostic marker for canine visceral leishmaniasis. Mem Inst Oswaldo Cruz 2005; 100(2): 197-203. PMid:16021309. http://dx.doi. org/10.1590/S0074-02762005000200015

Ross R. (1) note on the bodies recently described by Leishman-Donovan and (2) Further notes on Leishman's bodies. BMJ 1903; 2: 1261-1401. PMid:20761169 PMCid:PMC2514667. http://dx.doi.org/10.1136/ bmj.2.2237.1261

Solano-Gallego L, Riera C, Roura X, Iniesta L, Gallego M, Valladares $\mathrm{JE}$, et al. Leishmania infantum-specific IgG, IgG1 and IgG2 antibody responses in healthy and ill dogs from endemic areas. Evolution in the course of infection and after treatment. Vet Parasitol 2001; 96(4): 265276. http://dx.doi.org/10.1016/S0304-4017(00)00446-5

Sundar S, Rai M. Laboratory diagnosis of visceral leishmaniasis. Clin Diagn Lab Immunol 2002; 9(5): 951-958. PMid:12204943 PMCid:PMC120052.

Tasca KI, Starke-Buzetti WA, Tenorio MS, Paulan SC, Lima FL, Queiroz NMGP, et al. Exames parasitológicos, imunoistoquímicos e histopatológicos para detecção de Leishmania chagasi em tecidos esplênicos de cáes com leishmaniose visceral. Rev Bras Parasitol Vet 2009; 18(1): 27-33. PMid:19500457. http://dx.doi.org/10.4322/ rbpv.01801005

Zijlstra EE, Nur Y, Desjeux P, Khalil EAG, El-Hassan AM, Groen J. Diagnosing visceral leishmaniasis with the recombinant K39 strip test: experience from the Sudan. Trop Med Int Health 2001; 06(2): 108-113. http://dx.doi.org/10.1046/j.1365-3156.2001.00680.x 